\title{
CRITICAL DISCOURSE ANALYSIS (CDA) OF SINDO NEWSPAPER (CDA A MODEL OF VAN DIJK)
}

\begin{abstract}
This study aims at describing the text analysis, social cognition, social context, and ideology of sindo newspaper of Wednesday December $11^{\text {th }} 2013$ edition.. This study uses Critical Discourse Analysis method with a Teun A Van Dijk approach model. The data were in the form of news entitled "Putusan Luthfi Hasan Diharapkan Jadi Efek Jera". The data were analyzed with integrating the third dimension of Teun A Van Djik Discoure model in the unity analysis, they were text, social cognition, and social context. The results found that the Sindo Newspaper supported the work of the Corruption Eradication Commission (KPK) and the presiding judge of Corruption Court (Tipikor). The news in the edition of Wednesday, December $11^{\text {th }}$, 2013 "the ideology of Sindo Newspaper practically used to build the image of KPK and TIPIKOR to be more better in the society.
\end{abstract}

Keywords: Critical Discourse Analysis ( AWK), Sindo Newspaper, Van Dijk Model.

\section{ANALISIS WACANA KRITIS (AWK) KORAN SINDO (AWK MODEL VAN DIJK)}

\author{
Dewi Yana \\ Riau Kepulauan University \\ alifdewi@yahoo.com
}

\begin{abstract}
ABSTRAK
Tujuan penelitian ini adalah untuk mengetahui bagaimanakah analisis teks, kognisi sosial, kontek sosial dan ideology yang ditampilkan dalam Koran Sindo Edisi Rabu 11 Desember 2013. Metode yang digunakan adalah metode Analisis Wacana Kritis dengan menggunakan pendekatan model Teun A. van Dijk. Data dalam penelitian ini merupakan data yang berjenis berita dengan judul "Putusan Lutfi Hasan Diharapkan Jadi Efek Jera”. Tehnik analisis data dilakukan dengan menggunakan analisis wacana model Teun van Dijk. Inti analisis van Dijk adalah menggabungkan ketiga dimensi wacana ke dalam satu kesatuan analisis yaitu teks, kognisi sosial dan kontek sosial. Hasilnya menunjukkan bahwa Koran Sindo dalam hal ini bersikap mendukung kinerja Komisi Pemberantasan Korupsi (KPK) dan majelis hakim Tindak Pidana Korupsi ( tipikor). Pemberitaan Koran Sindo Edisi Rabu 11 Desember 2013 "Putusan Lutfi Diharapkan Jadi Efek Jera”. Memanfaatkan kesempatan praktik ideologinya untuk membangun citra KPK dan majelis hakim Tipikor bertambah baik dan positif di mata masyarakat Indonesia.
\end{abstract}

Kata Kunci: Analisis Wacana Kritis (AWK), Koran Sindo, Model Van Dijk. 


\section{Pendahuluan}

"Hidup ini dikendalikan oleh media massa". Kalimat itu tak dapat kita pungkiri bila kita lihat animo individu atau masyarakat terhadap berbagai program komunikasi melalui media massa seperti surat kabar, majalah, radio, televisi dan film. Belum lagi munculnya media on-line (internet). Sejak bangun tidur kemudian melakukan aktivitas harian hingga tidur kembali, kita tidak lepas dari terpaan atau menerpakan diri terhadap media massa. Dalam era kompetisi, era komunikasi, era perang citra atau lebih dikenal dengan era globalisasi, uberan informasi menjadi hal yang tidak dapat dibendung lagi

Dalam kaitannya sebagai institusi informasi, media menjadi sarana yang sangat strategis bagi pihak terkait dalam membangun opini publik yang mencerminkan ideology tertentu. Menurut Eriyanto, (2011:36), lewat media, ideologi yang dominan, baik yang buruk maupun yang baik, dapat dimapankan. Kemudian, berita yang disebarkan oleh media pada hakekatnya tidak identik dengan fakta peristiwa akan tetapi lebih kepada sebuah rekonstruksi realita yang dikembangkan sesuai dengan kepentingan yang hendak dicapai. Sehingga media bukan merupakan sarana yang netral yang menyampaikan fakta apa adanya terhadap masyarakat

Oleh karena itu, bahasa merupakan unsur penting yang bisa diamati untuk membongkar ideology yang tersembunyi dari media. Dan ini merupakan isu sentral dalam analisis wacana kritis. Menurut Eriyanto (2011: 6-7) pandangan kritis menganggap bahwa wacana melihat bahasa selalu terlibat dalam hubungan kekuasaan, terutama dalam pembentukan subjek, dan berbagai tindakan representasi yang terdapat dalam masyarakat. Karena memakai perspektif kritis, analisis wacana kategori ini disebut sebagai analisis wacana kritis

Terkait dengan situasi perpolitikan Indonesia yang penuh dengan dinamika, maka dapat dilihat bahwa bahasa yang banyak digunakan dalam media saat ini adalah bahasa dalam wacana politik dan hukum. Salah satu pemberitaan yang sempat hangat disoroti oleh media bahkan sampai saat ini adalah pemberitaan tentang kasus suap impor daging. Pemberitaan ini menjadi menarik karena melibatkan institusi Negara dan partai politik terutama antara KPK dan PKS.

Kasus suap impor daging ini berawal dari tertangkapnya Ahmad Fathonah di hotel Le Meridien, Jakarta Pusat pada tanggal 29 Januari 2013 yang diikuti dengan penangkapan Lutfi Hasan Ishaq yang merupakan ketua umum PKS. Kasus ini bukanlah satu-satunya kasus korupsi yang melibatkan ketua umum sebuah partai politik namun kasus ini menjadi semakin menarik karena Lutfi Hasan Ishaq langsung ditetapkan sebagi tersangka bahkan langsung ditahan oleh KPK yang belum pernah dilakukan oleh KPK sebelumnya kepada ketua umum partai lainnya meskipun sudah ditetapkan menjadi tersangka.

Selain itu pemberitaan terbaru terkait dengan isu suap impor daging sapi ini adalah isu tentang penjatuhan vonis terhadap LHI. LHI di vonis 16 tahun penjara dan denda sebesa Rp. 1 miliar. Vonis penjara tersebut terhitung sebagai vonis yang paling tinggi yang pernah diberikan kepada terdakwa kasus korupsi selama ini. Tak sedikit media yang menanggapi positif vonis tersebut namun ada juga yang meresponnya dengan negatif. oleh karena itu pemberitaan kasus ini menjadi penting untuk dianalisis secara kritis guna mengungkap latar belakang dan ideology yang mendasari para pembuat berita dalam mengembangkan isu pemberitaan kasus ini.

a. Rumusan Masalah

Berdasarkan latar belakang yang telah dipaparkan di atas, maka masalah dalam penelitian ini dapat dirumuskan sebagai berikut:Bagaimanakah analisis teks, kognisi sosial, konteks sosial dan ideologi yang ditampilkan dalam Koran Sindo Edisi Rabu 11 Desember 2013 "Putusan Luthfi Hasan Diharapkan Jadi Efek Jera”?

b. Tujuan Penelitian 
Tujuanhu penelitian ini adalah untuk mengetahui bagaimanakah analisis teks, kognisi sosial, kontek sosial dan ideology yang ditampilkan dalam Koran Sindo Edisi Rabu 11 Desember 2013 "Putusan Luthfi Hasan Diharapkan Jadi Efek Jera”.

c. Manfaat Penelitian

Penelitian ini diharapkan dapat memberi kontribusi secara teoretis dan pragmatis. Secara teoretis, penelitian ini diharapkan dapat memperkaya dan memperluas tema penelitian dalam bidang bahasa, khususnya analisis wacana kritis. Melalui analisis wacana pula diharapkan penelitian-penelitian mengenai bahasa dapat lebih aplikatif dan ramah terhadap situasi dan peristiwa sosial yang terjadi di masyarakat sehingga dapat menjadi solusi dari permasalahan yang ada di masyarakat. Secara pragmatis, penelitian ini diharapkan dapat memberi kesadaran kritis kepada institusi media dan pembaca media untuk lebih awas terhadap segala bentuk pemberitaan yang disalurkan melalui bahasa oleh media.

\section{Kerangka teoretis}

\section{a. Media Massa}

Media massa acap disebut sebagai the fourth estate (kekuatan keempat) dalam kehidupan sosial-ekonomi dan politik. Hal ini disebabkan oleh suatu persepsi tentang pesan yang dapat dimainkan media dalam kaitannya dengan pengembangan kehidupan sosialekonomi dan politik masyarakat (Sobur, 2009 : 30). Melalui media, berbagai pihak baik secara individu, kolektif maupun instansi pemerintah bisa membangun persepsi kepada khalayak ramai. Di samping sebagai alat untuk menyampaikan berita, penilaian, atau gambaran umum tentang banyak hal, media massa juga mampu berperan sebagai institusi yang dapat membentuk opini publik, bahkan menjadi kelompok penekan atas suatu gagasan yang harus diterima oleh pihak lain (Sobur, 2009:31).

Berdasarkan kemungkinan yang dapat diperankan itu, media massa merupakan sebuah kekuatan raksasa yang sangat diperhitungkan. Dalam berbagai analisis tentang kehidupan sosial, ekonomi, dan politik, media sering ditempatkan sebagai salah satu variabel determinan. Bahkan media, terlebih dalam posisinya sebagai suatu institusi informasi, dapat pula dipandang sebagai faktor yang paling menentukan dalam proses-proses perubahan sosial-budaya dan politik. Oleh karena itulah dalam konteks media massa sebagai institusi informasi, Karl Deutsch, menyebutnya sebagai "urat nadi pemerintah" (the nerves of goverment) (Sobur, 2009 : 31).

Bagi sebagian orang, media massa hanya berupaya menemukan kebenaran dan kenyataan itu. Lalu memberikannya kepada publik. Media massa dianggap tidak lebih dari "alat komunikasi” yang netral dan kosong dalam dirinya sendiri. Ia hanya berisi apabila diisi pesan oleh komunikator kepada pihak tertentu. Tampaknya oleh sebagian orang lagi, media massa tidak pernah dan tidak akan lebih banyak memberikan kebenaran atau "kenyataan apa adanya”. Ia lebih banyak menjanjikan mimpi dan fiksi (Sobur, 2009 : 33).

b. Berita dan wacana

Eriyanto mengatakan bahwa independen dan objektif, merupakan dua kata kunci yang menjadi kiblat dan klaim setiap jurnalis di seluruh dunia.Seorang jurnalis selalu menyatakan dirinya telah bertindak objektif, seimbang dan tidak berpihak pada kepentingan apapun kecuali keprihatinan atas hak masyarakat untuk mengetahui kebenaran (Eriyanto, 2004 : v). Ia menambahkan bahwa meskipun sikap independen dan objektif menjadi kiblat setiap jurnalis, pada kenyataannya kita sering kali mendapatkan suguhan berita yang beraneka warna dari sebuah peristiwa yang sama. Maka, dengan membandingkan beberapa pemberitaan media, sangat mungkin kita akan menemukan kesimpulan yang setara, bahwa media apapun tidak bisa lepas dari bias-bias, baik yang berkaitan dengan ideologi, politik, ekonomi, sosial, budaya, bahkan agama. Tidak ada satupun media yang memiliki sikap independensi dan objektivitas yang absolut (Eriyanto, 2004 : vi).

Dalam kerangka pembentukan opini publik, media massa umumnya melakukan tiga kegiatan sekaligus. Ibnu Hamad, sebagaimana dikutip Hafizoh menulis, pertama media massa menggunakan simbol-simbol politik (language of politic), kedua, melaksanakan strategi pengemasan pesan (framing strategies), dan ketiga, adalah melakukan fungsi agenda media (agenda setting function). 
Ketika melakukan ketiga tindakan tersebut, media massa dapat dipengaruhi oleh berbagai faktor internal dan eksternal (Hafizoh, 2007 : 39). Faktor internal seperti tekanan redaksional tertentu mengenai suatu kekuatan politik, kepentingan politik para pengelola media, relasi media dengan kekuatan politik tertentu. Sedangkan faktor eksternal seperti tekanan pasar pembaca maupun pemirsa, sistem kekuasaan yang berlaku dan kekuatan-kekuatan luar lainnya. Suatu peristiwa tertentu dapat menimbukan opini publik yang berbeda-beda tergantung dari cara masing-masing media melaksanakan ketiga tindakan tersebut. Oleh karenanya, dengan adanya kemungkinan perbedaan pembentukan opini publik oleh masing-masing media, dapat dikatakan bahwa realitas yang dibawa media massa ke tengah masyarakat bisa jadi bukanlah realitas yang sebenarnya, tapi realitas bentukan/rekayasa (Hafizoh, $2007: 40$ ).

\section{c. Analisis Wacana Kritis}

Dalam analisis wacana kristis (Critical Discourse Analysis/CDA) wacana disini tidak dipahami semata sebagai studi bahasa. Analisis wacana kritis melihat bahasa sebagai faktor penting, yakni bagaimana bahasa digunakan untuk melihat ketimpangan kekuasaan dalam masyarakat terjadi (Eriyanto, 2001 : 7). Salah satu sifat dasar dari teori kritis adalah selalu curiga dan mempertanyakan kondisi masyarakat dewasa ini, karena kondisi masyarakat yang kelihatannya produktif, dan bagus tersebut sesungguhnya terselubung struktur masyarakat yang menindas dan menipu kesadaran khalayak (Eriyanto, $2001: 24$ )

Mengutip Fairclough dan Wodak, analisis wacana kritis menyelidiki bagaimana melalui bahasa kelompok sosial yang ada saling bertarung dan mengajukan versinya masingmasing. Berikut ini disajikan karakteristik penting dari analisis wacana kritis. Bahasa ini diambil dari tulisan Teun A. VanDijk, Fairclough, dan Wodak.(Eriyanto, 2001: 8-13)

1. Tindakan

Wacana dapat dipahami sebagai tindakan (actions) yaitu mengasosiasikan wacana sebagai bentuk interaksi. Seseorang berbicara, menulis, menggunakan bahasa untuk berinteraksi dan berhubungan dengan orang lain. Wacana dalam prinsip ini, dipandang sebagai sesuatu yang bertujuan apakah untuk mendebat, mempengaruhi, membujuk, menyangga, bereaksi dan sebagainya. Selain itu wacana dipahami sebagai sesuatu yang diekspresikan secara sadar, terkontrol bukan sesuatu di luar kendali atau diekspresikan secara sadar (Eriyanto, $2001: 8$ )

2. Konteks

Analisis wacana kritis mempertimbangkan konteks dari wacana seperti latar, situasi, peristiwa dan kondisi. Wacana dipandang diproduksi dan dimengerti dan dianalisis dalam konteks tertentu. Guy Cook menjelaskan bahwa analisis wacana memeriksa konteks dari komunikasi: siapa yang mengkomunikasikan dengan siapa dan mengapa; khalayaknya, situasi apa, melalui medium apa, bagaimana, perbedaan tipe dan perkembangan komunikasi dan hubungan masing-masing pihak. Tiga hal sentralnya adalah teks (semua bentuk bahasa, bukan hanya kata-kata yang tercetak dilembar kertas, tetapi semua jenis ekspresi komunikasi). Konteks (memasukan semua jenis situasi dan hal yang berada dilar teks dan mempengaruhi pemakaian bahasa, situsai dimana teks itu diproduksi serta fungsi yang dimaksudkan). Wacana dimaknai sebagai konteks dan teks secara bersama. Titik perhatianya adalah analisis wacana menggambarkan teks dan konteks secara bersama-sama dalam proses komunikasi (Eriyanto, $2001:$ 10)

3. Historis

Yang dimaksud dalam karakteristik ini adalah menempatkan wacana dalam konteks sosial tertentu. Berarti wacana diproduksi dalam konteks dan tidak dapat dimengerti tanpa menyertakan konteks yang menyertainya. Oleh karena itu, pada waktu melalukan analisis perlu tinjauan untuk mengerti mengapa wacana yang berkembang atau dikembangkan seperti itu, mengapa bahasa yang dipakai seperti itu, dan seterusnya.

\section{Kekuasaan}

Analisis wacana kritis mempertimbangkan elemen kekuasaan. Wacana dalam bentuk teks, percakapan atau apa pun tidak dipandang sebagai sesuatu yang alamiah wajar dan netral tetapi merupakan bentuk pertarungan kekuasaan. Konsep kekuasaan yang dimaksudkan adalah salah satu kunci hubungan antara wacana dan masyarakat. Kekuasaan itu dalam hubungannya 
dengan wacana, penting untuk melihat apa yang disebut sebagai kontrol. Bentuk kontrol terhadap wacana tersebut bisa bermacammacam, bisa berupa kontrol atas konteks, selain itu kontrol juga diwujudkan dalam bentuk mengontrol struktur wacana (Eriyanto, 2001 :11).

\section{Ideologi}

Ideologi adalah salah satu konsep sentral dalam analisis wacana kritis karena setiap bentuk teks, percakapan dan sebagainya adalah praktik ideologi atau pancaran ideologi tertentu. Wacana bagi ideologi adalah medium melalui mana kelompok dominan mempersuasi dan mengkomunikasikan kepada khalayak kekuasaan yang mereka miliki sehingga absah dan benar. Ideologi dari kelompok dominan hanya efektif jika didasarkan pada kenyataan bahwa anggota komunitas termasuk yang didominasi menganggap hal tersebut sebagai kebenaran dan kewajaran(Eriyanto, 2001 : 13).

Ideologi dimaksudkan untuk mengatur masalah tindakan dan praktik individu atau anggota suatu kelompok. Dalam perspektif ini, ideologi mempunyai beberapa implikasi penting sebagaimana di katakana oleh Teun A. Van Dijk (Eriyanto,2001 : 14) . Pertama, ideologi secara inheren bersifat sosial, tidak personal atau individual ; ia membutuhkan share diantara anggota kelompok, organisasi atau kolektivitas dengan orang lainnya. Kedua, ideologi meskipun bersifat sosial, ia digunakan secara internal diantara anggota kelompok atau komunitas. Oleh karena itu, ideologi tidak hanya menyediakan fungsi koordinatif dan kohesi tetapi juga membentuk identitas diri kelompok, membedakan dengan kelompok lain. Oleh karena itu, analisis wacana tidak bisa menempatkan bahasa secara tertutup, tetapi harus melihat konteks, terutama bagaimana ideology dari kelompok-kelompok yang ada tersebut berperan dalam membentuk wacana.

Wacana model van Dijk digambarkan mempunyai tiga dimensi/bangunan : teks, kognisi sosial, dan konteks sosial (Eriyanto, 2001: 224-261). Inti analisis van Dijk adalah menggabungkan ketiga dimensi wacana tersebut ke dalam satu kesatuan analisis.

Dimensi pertama analisis model Van Dijk yaitu dimensi teks. Pada level ini yang diteliti adalah bagaimana struktur teks dan strategi wacana yang dipakai untuk menegaskan suatu tema tertentu. Van Dijk melihat suatu teks terdiri atas beberapa struktur/tingkatan yang masingmasing bagian saling mendukung, ia membagi dalam tiga tingkatan, yaitu struktur makro, superstruktur, dan struktur mikro(Eriyanto, 2001 : 224). Adapun penjelasan dari tiga tingkatan dalam dimensi teks menurut van Dijk adalah sebagai berikut :

1. Sruktur Makro

Struktur makro merupakan makna global/umum dari suatu teks yang dapat diamati dengan melihat topik atau tema yang dikedepankan dalam suatu berita. Elemen tematik menunjuk pada gambaran umum dari suatu teks. Bisa juga disebut sebagai gagasan inti, ringkasan, atau yang utama dari suatu teks. Topik menggambarkan apa yang ingin diungkapkan oleh wartawan dalam pemberitaannya (Eriyanto, 2001: 229). Menurut van Dijk, seperti dikutip Sobur, dari topik kita bisa mengetahui masalah dan tindakan yang diambil oleh komunikator dalam mengatasi suatu masalah. Tindakan, keputusan, atau pendapat dapat diamati pada struktur makro dari suatu wacana. Topik akan di dukung oleh beberapa sub-topik. Masing-masing sub topik ini mendukung, memperkuat, bahkan membentuk topik utama. (Sobur,2009 : 76).

Gagasan van Dijk ini didasarkan pada pandangan ketika wartawan meliput suatu peristiwa dan memandang suatu masalah didasarkan pada suatu mental/pikiran tertentu. Kognisi atau mental ini secara jelas dapat dilihat dari topik yang dimunculkan dalam berita. Karena topik disini dipahami sebagai mental atau kognisi wartawan, makanya tak heran jika semua elemen dalam berita mengacu dan mendukung topik dalam berita (Eriyanto, 2001 : 231).

2. Superstruktur

Superstruktur merupakan struktur wacana yang berhubungan dengan kerangka suatu teks, bagaimana bagian-bagian teks tersusun ke dalam berita secara utuh. Teks atau wacana umumnya mempunyai skema atau alur dari pendahuluan sampai akhir. Alur tersebut menunjukkan bagaimana bagian-bagian dalam teks disusun dan diurutkan hingga membentuk kesatuan arti (Eriyanto, 2001 : 232). Arti penting dari skematik adalah strategi wartawan untuk 
mendukung topik tertentu yang ingin disampaikan dengan menyusun bagian-bagian dengan urutan tertentu. Skematik memberikan tekanan mana yang didahulukan, dan bagian mana yang bisa kemudian sebagai strategi untuk menyembunyikan informasi penting. Upaya penyembunyian itu dengan menempatkan dibagian akhir agar terkesan kurang menonjol (Eriyanto, $2001: 234$ ).

3. Struktur mikro

Struktur mikro merupakan makna wacana yang dapat diamati dari bagian kecil dari suatu teks yakni kata, kalimat, proposisi, anak kalimat, paraphrase, dan gambar. Ada empat hal yang diamati dalam struktur mikro ini, yaitu semantik, sintaksis, stilistik, dan retoris.

a. Semantik

Semantik adalah makna yang ingin ditekankan dalam teks. Dalam studi linguistik konvensional, makna kata dihubungkan dengan arti yang terdapat dalam kamus, sedangkan dalam analisis wacana, makna kata adalah praktik yang ingin dikomunikasikan sebagai suatu strategi. Semantik dalam skema van Dijk dikategorikan sebagai makna lokal (local meaning), yakni makna yang muncul dari hubungan antarkalimat, hubungan antarproposisi yang membangun makna tertentu dalam suatu bagunan teks. Semua strategi semantic selalu dimaksudkan untuk menggambarkan diri sendiri atau kelompok sendiri secara positif, sebaliknya menggambarkan kelompok lain secara buruk, sehingga menghasilkan makna yang berlawanan (Sobur, 2009 : 78).

Ada bebrapa elemen yang diamati dalam semantik ini, yaitu latar, detil, maksud, praanggapan, dan nominalisasi. Latar merupakan elemen wacana yang dapat dijadikan alasan pembenar gagasan yang diajukan dalam suatu teks. Oleh karenanya, latar teks dapat digunakan untuk membongkar apa maksud yang ingin disampaikan wartawan (Eriyanto, 2001 :235). Detil berhubungan dengan kontrol informasi yang ditampilkan seseorang (komunikator). Komunikator akan menampilkan secara berlebihan informasi yang menguntungkan dirinya atau citra yang baik (Eriyanto, 2001 : 238). Maksud melihat apakah teks itu disampaikan secara eksplisit ataukah tidak. Umumnya, informasi yang merugikan akan diuraikan secara tersamar, implisit dan tersembunyi. Tujuan akhirnya adalah kepada publik hanya disajikan informasi yang menguntungkan komunikator (Eriyanto, 2009 : 240). Praanggapan merupakan pernyataan yang digunakan untuk mendukung makna suatu teks dengan memberikan premis yang dipercaya kebenarannya. Ia merupakan fakta yang belum terbukti kebenarannya, tetapi dijadikan dasar untuk mendukung gagasan tertentu (Eriyanto, 2001 : 256). Nominalisasi berhubungan dengan pertanyaan apakah wartawan memandang objek sebagai suatu kelompok.

b. Sintaksis

Secara etimologis, kata sintaksis berasal dari kata Yunani (sun = "dengan" + tattein = "menempatkan"). Sintaksis secara etimologis berarti menempatkan bersama-sama kata-kata menjadi kelompok kata atau kalimat (Sobur, 2009 : 80). Berkaitan dengan bagaimana pendapat disampaikan. Elemen-elemen yang diamati antara lain bentuk kalimat, koherensi, dan kata ganti.

Bentuk kalimat adalah segi sintaksis yang berhubungan dengan cara berpikir logis, yaitu prinsip kausalitas. Terdapat unsur subyek dan predikat dalam setiap kalimat. Bentuk kalimat ini menentukan apakah subyek diekspresikan secara eksplisit atau implisit di dalam teks berita (Sobur, 2009 :81). Sebagaimana dikutip Sobur memberikan keterangan koherensi dengan dua pengertian, yaitu kohesi dan koneksi. Kohesi adalah perbuatan atau keadaan menghubungkan, mempertalikan. Sedangkan koneksi adalah hubungan yang cocok dan sesuai atau kebergantungan satu sama lain yang rapi, beranjak dari hubungan-hubungan alamiah bagian-bagian atau hal-hal satu sama lain, seperti dalam argumen suatu rentetan penalaran (Sobur, 2009 : 80). Dalam analisis wacana, koherensi adalah pertalian atau jalinan antarkata, proposisi atau kalimat. Dua buah kalimat atau proposisi yang menggambarkan fakta yang berbeda dapat dihubungkan dengan memakai koherensi, sehingga fakta yang tidak berhubungan sekalipun dapat menjadi berhubungan ketika komunikator menghubungkannya (Sobur, 2009 : 81).

Kata Ganti merupakan elemen untuk memanipulasi bahasa dengan menciptakan suatu komunitas imajinatif. Kata ganti merupakan alat yang dipakai komunikator untuk menunjukkan 
dimana posisi seseorang dalam wacana (Eriyanto, 2001 : 253).

c. Stilistik

Alex Sobur mengutip pendapat Panuti Sudjiman yang mengatakan bahwa pusat perhatian stilistika adalah style, yaitu cara yang digunakan seorang pembicara atau penulis untuk menyatakan maksudnya dengan menggunakan bahasa sebagai sarana. Dengan demikian style dapat diterjemahkan sebagai gaya bahasa (Sobur,2009 : 83). Elemen yang diamati dalam stilistik adalah leksikon. Pada analisis wacana, leksikon pada dasarnya menandakan bagaimana seseorang melakukan pemilihan kata atas berbagai kemungkinan kata yang tersedia (Eriyanto, 2001 : 255)

\section{d. Retoris}

Berkaitan dengan bagaimana cara wartawan menyampaikan pendapat terhadap sebuah berita. Retoris mempunyai fungsi persuasif, dan berhubungan erat dengan bagaimana pesan itu ingin disampaikan kepada khalayak (Sobur, 2009 : 84). Elemen yang diamati meliputi grafis, metafora, dan ekspresi.

Grafis adalah bagian untuk memeriksa apa yang ditekankan atau ditonjolkan (yang berarti dianggap penting) oleh seseorang yang dapat diamati dalam teks (Eriyanto, 2001 : 258). Metafora adalah bagian yang berisi kata-kata berupa kiasan, ungkapan, metafora, yang dimaksudkan sebagai ornamen atau bumbu dari suatu teks. Akan tetapi pemakaian metafora tertentu bisa jadi petunjuk utama untuk mengerti makna suatu teks (Eriyanto, 2001 : 259). Ekspresi merupakan bentuk intonasi komunikator yang dapat mensugestikan komunikan untuk memperhatikan atau mengabaikan bagian tertentu, dalam sebuah pesan gagasan yang dikehendaki komunikator.

Dimensi kedua analisis model Van Dijk adalah kognisi sosial. Level ini mempelajari proses produksi teks berita yang melibatkan kognisi individu dari wartawan. Level ini juga dihubungkan dengan proses produksi berita. Titik kunci dalam memahami produksi berita adalah dengan meneliti proses terbentuknya berita. Kemudian produksi berita sebagian besar dan terutama terjadi pada proses mental dalam kognisi seorang wartawan (Eriyanto, 2001 : 266). Analisis kognisi sosial menekankan, bagaimana peristiwa dipahami, didefinisikan, dianalisis, dan ditafsirkan dalam suatu model dalam memori. Model ini menggambarkan bagaimana : tindakan atau peristiwa yang domain, partisipan, waktu dan lokasi, keadaan, objek yang relevan, atau perangkat tindakan dibentuk dalam struktur berita. Wartawan menggunkana model untuk memahami peristiwa yang telah diliputnya. Model itu memasukkan opini, sikap, perspektif, dan informasi lainnya.

Dimensi ketiga dari analisis van Dijk adalah analisis konteks sosial. Level ketiga ini mempelajari bangunan wacana yang berkembang dalam masyarakat akan suatu masalah Titik penting dari analisis ini adalah untuk menunjukkan bagaimana makna yang dihayati bersama, kekuasaan sosial diproduksi lewat praktik diskursus dan legitimasi. Menurut van Dijk sebagaimana dikutip Eriyanto, dalam analisis mengenai masyarakat ini, ada dua poin yang penting : kekuasaan (power) dan akses (acces) (Eriyanto, 2004 : 271).

d. Profil Koran Sindo ( Harian Seputar Indonesia)

Harian Seputar Indonesia atau akrab disebut Koran SINDO adalah sebuah surat kabar di Indonesia yang terbit perdana, pada 30 Juni 2005. Surat kabar ini dilahirkan oleh PT Media Nusantara Informasi (MNI), anak perusahaan PT Media Nusantara Citra Tbk (MNC). Koran Sindo ini terbit selama 7 hari selama 1 minggu, dengan format ukuran panjang 7 kolom dan tinggi $54 \mathrm{~cm}$. Edisi Reguler terbit 40 halaman dengan 3 bagian sedangkan Minggu terbit 40 halaman edisi akhir minggu.

Target pembacanya adalah masyarakat kelas menengah ke atas, pendidikan Sarjana, segmentasi usia dari 18 tahun sampai dengan 40 tahun. Dengan diferensiasi pembaca laki-laki sebanyak $60 \%$ dan pembaca wanita sebanyak $40 \%$. Target distribusi Koran SIndo adalah kotakota besar di seluruh Indonesia dengan jumlah oplah sebesar 336.000 pembaca. Slogannya adalah "Sumber Referensi Terpercaya”(http://id.wikipedia.org).

Koran Sindo ditujukan untuk memudahkan sekaligus memenuhi kebutuhan pembaca dalam satu keluarga. Pada saat sang bapak memilih news, sang ibu bisa leluasa membaca lifestyle, sedangkan si anak bebas membaca sport. Atau sang bapak bisa membawa news ke kantor dengan meninggalkan lifestyle untuk dibaca ibu 
di rumah, sementara si anak memasukkan sport ke dalam tas untuk dibaca dalam perjalanan. Pendeknya, mereka bisa bertukar section tanpa harus mengganggu keasyikan masing-masing.

Koran Sindo hadir setiap pagi dengan sajian berita-berita yang akurat, mendalam, penuh gaya dan warna. Koran ini juga menyapa pembaca dengan sentuhan jurnalisme khas untuk selalu memberikan lebih dari sekadar berita. Apalagi ditunjang dengan kreatifitas visual yang progresif dan tidak konservatif, Koran Sindo yakin akan menjadi media yang unik.

Sajian berita yang bersahabat, karena pemanfaatan bahasa dan image yang ramah aktual dan informatif, karena berita terkini disajikan dengan ringkas dan jelas dengan topiktopik yang hangat. Koran yang menghibur karena didukung oleh desain yang menarik dan tidak membuat kening berkerut. Mampu mengakomodasi Feature Lifestyle dan Infotainment sekuat berita. Sajian berita yang bersifat Non Partisan atau tidak memihak dan dapat dipercaya. Koran SIndo "Satu Koran semua berita”. Demikianlah jargon yang dipakai. (http://www.seputar-indonesia.com).

Koran sindo adalah koran nasional satusatunya yang terbit di daerah dengan penyajian berita lokal yang dominan dan selalu dimuat sebagai headline dan berita-berita utama lainnya (bulan berupa sisipan). Berita lokal Koran Sindo diliput dari narasumber / kejadian langsung secara cepat dan akurat oleh wartawan-wartawan Sindo daerah yang berkompeten. Koran Sindo tampil sebagai koran nasional dengan local content yang menjadikannya milik masyarakat di daerah.

Selanjutnya visi Koran Sindo adalah menjadi koran keluarga yang ideal di wilayah Indonesia. Koran keluarga di sini meliputi informasi berita keluarga, olahraga, hiburan, edukatif, dan bisnis. Sedangkan misinya adalah menjadi koran keluarga nomor satu yang harganya terjangkau dan dekat dengan pembacanya. Dengan harga yang terjangkau, berita yang disajikan lebih komplit atau lengkap sehingga setelah membaca koran Sindo tidak perlu lagi membeli majalah, tabloid atau yang lainnya.

\section{Metode penelitian}

1. Pendekatan penelitian
Metode yang digunakan adalah metode Analisis Wacana Kritis dengan menggunakan pendekatan model Teun A. van Dijk. Model ini sering disebut sebagai kognisi sosial. Menurutvan Dijk, penelitian atas wacana tidak cukup hanya didasarkan pada analisis atas teks saja karena teks hanyalah hasil dari suatu praktikproduksi yang harus juga diamati. Di sini harus dilihat juga bagaimana suatu teks diproduksi, sehingga kita memperoleh suatu pengetahuan kenapa teks bisa semacam itu (Eriyanto, $2001: 221$ ).

\section{Sumber Data}

Data dalam penelitian ini merupakan data yang berjenis berita dengan judul "Putusan Lutfi Hasan Diharapkan Jadi Efek Jera” yang terdapat dalam Koran Sindo edisi Rabu 11 Desember 2013.

\section{Tehnik Analisa Data}

Tehnik analisis data dilakukan dengan menggunakan analisis wacana model Teun van Dijk. Inti analisis van Dijk adalah menggabungkan ketiga dimensi wacana ke dalam satu kesatuan analisis yaitu teks, kognisi sosial dan kontek sosial. Suatu teks terdiri atas beberapa struktur/ tingkatan yang masingmasing bagian saling mendukung. Tingkatan tersebut terdiri dari struktur makro, superstruktur, dan struktur mikro. (Eriyanto, 2001 : 228-229).

\section{Hasil penelitian}

Penelitian atas wacana tidak cukup hanya didasarkan pada analisis atas teks semata, karena teks hanya hanya hasil dari suatu praktik produksi yang harus juga diamati. Selain itu dalam penelitian atas wacana juga harus menganalisa secara kritis atas kognisi sosial dan konteks sosial yang turut membangunnya (Eriyanto, 2005 : 221). Adapun berita yang dianalisis adalah berita "Putusan Luthfi Hasan Diharapkan Jadi Efek Jera” pada koran sindo edisi Rabu 11 Desember 2013.

\section{Analisis Teks}

\section{a. Tematik}

Elemen wacana yang diamati terdiri dari topik atau tema yang merupakan inti gagasan berita yang ingin disampaikan wartawan Koran Sindo kepada khalayak. Tema yang diangkat dalam berita ini mengenai vonis LHI yang 
dinilai bisa menjadi efek jera dalam pemberantasan korupsi di Indonesia.

\section{b. Skematik}

Elemen wacana yang diamati adalah skema teks, atau alur berita, dari pendahuluan sampai akhir. Di sini Koran Sindo memulai menuliskan pendapat guru besar ilmu hukum Universitas Sebelas Maret (UNS) Solo Jamal Wiwoho dan pakar hukum pidana UIN Syarif Hidayatullah Jakarta Andi Syafrani. Jamal mengungkapkan, vonis tinggi Luthfi merupakan langkah maju dalam upaya membabat habis korupsi. Jamal mengingatkan, langkah hukum berupa banding yang ditempuh Luthfi bisa menjadi dilema dan simalakama seandainya tidak diperhitungkan dengan matang.

Pada bagian pertengahan dari tubuh berita, Koran sindo menuliskan bahwa Majelis hakim Pengadilan Tipikor Jakarta mengganjar Luthfi dengan hukuman 16 tahun penjara disertai denda Rp1 miliar subsider satu tahun kurungan, Vonis ini dijatuhkan secara akumulatif dari kasus suap pengurusan kuota impor daging sapi PT Indoguna Utama di Kementerian Pertanian dan tindak pidana pencucian uang. Dan majelis memerintahkan merampas harta kekayaan Lutfi Hasan Ishaq.

Di bagian akhir berita, Koran Sindo menuliskan pandangan dari Bambang Widjojanto (mantan Ketua Yayasan Lembaga Bantuan Hukum Indonesia / YLBHI), Johan Budi SP (Jubir KPK) dan Anis Matta (Presiden PKS). Bambang menegaskan bahwa vonis majelis hakim tipikor kepada Luthfi menunjukkan bahwa mantan anggota DPR Komisi I itu terbukti melakukan tindak pidana korupsi dan pencucian uang baik secara aktif maupun pasif. Johan Budi ,menyebutkan kasus dugaan suap pengurusan kuota impor daging sapi pada Kementerian Pertanian terus berjalan. Terakhir, Anis Matta mengungkapkan bahwa pihak PKS menghormati proses hukum yang menimpa Luthfi.

Dari keseluruhan berita Koran Sindo ini, media ini hendak memaparkan bahwa vonis LHI merupakan sebuah keputusan berat yang diharapkan bisa membuat jera para koruptor guna menuntaskan kasus-kasus korupsi.

c. Semantik

Semantik adalah makna yang ingin ditekankan dalam teks. Dikategorikan sebagai makna yang muncul dari hubungan antar kalimat, yang akan disampaikan pada khalayak dari struktur teks yang dibangun Koran Sindo. Elemen wacana yang diamati meliputi :

1) Latar

Latar yang dipilih Koran Sindo untuk mendukung pemberitaannya mengenai kasus suap impor daging sapi. Koran Sindo menuliskan bahwa pemeriksaan terhadap para saksi terus dilakukan yang beratrti bahwa kasus dugaan suap pengurusan kuota impor daging sapi pada Kementerian Pertanian terus berjalan. Hal ini dipertegas oleh Johan Budi SP selaku JUBIR KPK.

2) Detil

Elemen wacana yang berhubungan dengan control informasi, dalam Koran Sindo ditampilkan seperti tertulis dalam paragraf di bawah ini :

Dalam TPPU, majelis hakim menyatakan terdakwa terbukti bersalah secara sah dan meyakinkan sengaja menyembunyikan, menyamarkan, membayarkan, membelanjakan, menitipkan, mentransfer berbagai harta yang didapat dari tindak pidana korupsi. Luthfi terbukti memiliki profil keuangan menyimpang jika dibandingkan penghasilan sebelum dan saat menjabat sebagai anggota DPR 2004-2009.

Dari paratgraf tersebut, wartawan menguraikan secara detail dan terperinci bahwa menurut majelis hakim dalam TPPU terdakwa terbukti bersalah. Oleh karenanya, wajar kalau harta LHI dirampas dan ia di putuskan dengan vonis penjara selama 16 tahun.

3) Maksud

Informasi yang menguntungkan komunikator akan diuraikan secara eksplisit dan jelas. Sebaliknya informasi yang merugikan akan diuraikan secara tersamar, implisit dan tersembunyi. Tujuan akhirnya publik hanya disajikan informasi yang menguntungkan komunikator. Pada paragraph awal koran sindo menuliskan:

"Vonis itu akan menjerakan walaupun sesungguhnya belum maksimal,” ujar Jamal kemarin. Dia menilai, dalam kasus ini pernyataan kuasa hukum bahwa Luthfi tidak bersalah adalah hal yang wajar. Sebab memang belum pernah ada koruptor mengakui kejahatannya. Yang pasti, dalam amar putusannya majelis hakim yang diketuai 
Gusrizal Lubis menyatakan Luthfi terbukti secara sah dan meyakinkan menerima suap dan melakukan tindak pidana pencucian uang (moneylaundering).

Andi Syafrani menilai vonis penjara 16 tahun bagi Luthfi merupakan ganjaran tertinggi yang diterima politisi terdakwa korup. Dengan vonis tersebut, seharusnya para penjahat kerah putih bisa jeri dan jera untuk melakukan aksinya. "Jika para pelaku korupsi masih punya rasa takut, saya kira harusnya vonis LHI jadi pelajaran berarti untuk menghentikan perilaku korup," ujar Syafrani.

Dalam hal ini wartawan menggunakan elemen maksud dengan mengutip langsung pendapat dari guru besar ilmu hukum Universitas Sebelas Maret (UNS) Solo Jamal Wiwoho dan pakar hukum pidana UIN Syarif Hidayatullah Jakarta Andi Syafrani. Dari pernyataan tersebut wartawan menjelaskan secara eksplisit dan jelas bahwa vonis terhadap LHI bisa menjadi efek jera dalam pemberantasan korupsi di Indonesia.

\section{Praanggapan}

Pernyataan yang digunakan untuk mendukung makna suatu teks dengan memberikan premis yang dipercaya kebenarannya sehingga tidak perlu dipertanyakan lagi.

Jamal mengingatkan, langkah hukum berupa banding yang ditempuh Luthfi bisa menjadi dilema dan simalakama seandainya tidak diperhitungkan dengan matang. "Pengadilan tinggi (PT) bisa menguatkan atau menambah atau mengurangi hukuman penjara dan denda atas putusan Pengadilan Tipikor Jakarta tersebut," katanya.

Dalam kalimat tersebut, nampaknya Koran Sindo menekankan pernyataan Jamal Wiwoho, yang menyatakan bahwa langkah banding yang dilakukan Lutfi bisa jadi akan mengurangi hukuman nya, namun sebaliknya bisa pula memperberatnya.

d. Sintaksis

1) Kata Ganti

- "Jika para pelaku korupsi masih punya rasa takut, saya kira harusnya vonis LHI jadi pelajaran berarti untuk menghentikan perilaku korup," ujar Syafrani.
- Bambang menyatakan, vonis majelis hakim tipikor kepada Luthfi menunjukkan bahwa mantan anggota DPR Komisi I itu terbukti melakukan tindak pidana korupsi dan pencucian uang baik secara aktif maupun pasif. "Meskipun ada dissenting opinion (pendapat berbeda) hakim dan menurut saya agak salah, tapi bisa dibuktikan ada kejahatan di situ. Dan bukan hanya tipikor, tapi juga TPPU," tegasnya.

Dalam menulis pendapat pakar Hukum UIN Syarif Hidayatullah, Andi Syafrany dan anggota KPK Bambang Widjajanto , wartawan Koran Sindo menggunakan kata ganti "saya" yang menggambarkan bahwa sikap tersebut merupakan sikap resmi Andi Safrani dan Bambang sendiri. Pihak Koran Sindo menunjukkan bahwa mereka dengan yakin memberikan pendapat mereka sendiri bukan rekayasa dari wartawan Koran Sindo.

\section{2) Koherensi}

Pertalian atau jalinan antar kata, proposisi atau kalimat. Koherensi mencoba menghubungkan dua buah kata, kalimat, atau proposisi yang menggambarkan fakta yang berbeda.

Jamal mengingatkan, langkah hukum berupa banding yang ditempuh Luthfi bisa menjadi dilema dan simalakama seandainya tidak diperhitungkan dengan matang. "Pengadilan tinggi (PT) bisa

menguatkan atau menambah atau mengurangi hukuman penjara dan denda atas putusan Pengadilan Tipikor Jakarta tersebut," katanya.

Tampaknya kata "menambah" dan "mengurangi" dalam paragraph di atas merupakan kata yang bertolak belakang, akan tetapi dengan penggunaan kata sambung "atau”, dua kata tersebut tampak koheren untuk mendukung hukuman penjara dan denda terhadap proses banding yang ditempuh LHI.Selain paragraf tersebut, wartawan Koran Sindo juga menggunakan pertentangan. Dengan memakai kata "meskipun” dan "tapi”. Seperti dalam paragraf berikut ini :

Bambang menyatakan, vonis majelis hakim tipikor kepada Luthfi menunjukkan bahwa mantan anggota DPR Komisi I itu terbukti melakukan tindak pidana korupsi dan pencucian uang baik secara aktif maupun pasif. "Meskipun ada dissenting opinion (pendapat 
berbeda) hakim dan menurut saya agak salah, tapi bisa dibuktikan ada kejahatan di situ. Dan bukan hanya tipikor, tapi juga TPPU," tegasnya.

Dari paragraf tersebut, wartawan Koran Sindo ingin menyampaikan bahwa menurut anggota KPK, Bambang Widjajanto memang ada perbedaan pendapat antara para hakim dalam kasus LHI akan tetapi kejahatan dalam kasus tersebut tetap terbukti.

3) Bentuk Kalimat

Merupakan segi sintaksis yang berhubungan dengan cara berpikir logis, yaitu prinsip kasualitas atau sebab akibat. Terdapat unsur subjek dan unsur predikat dalam setiap kalimat. Dalam kalimat yang berstruktur aktif, seseorang menjadi subjek dari pernyatannya, sedangkan dalam kalimat pasif, seseorang dijadikan objek dari pernyataannya.

Praktik pencucian uang Luthfi dilakukan dari kurung tahun 2003 sampai 2013. Dalam putusannya, majelis memerintahkan merampas harta kekayaan politikus kelahiran Malang itu.

Kalimat di atas merupakan kalimat kausalitas akibat praktek pencucian uang maka harta kekayaan akan dirampas. Tampaknya kalimat yang dipilih Koran Sindo dituliskan secara eksplisit bahwa ia mendukung putusan majelis hakim untuk merampas karta kekayaan para koruptor yang diperoleh dari hasil praktek korupsi.

e. Stilistik

Elemen wacana teks yang diamati adalah :

1) Leksikon

Menandakan bagaimana seseorang melakukan pemilihan kata atas kemungkinan kata yang tersedia.

Vonis penjara dan denda Rp1 miliar yang disertai penyitaan aset itu diharapkan bisa mengerem terjadinya korupsi dan membuat takut calon koruptor.

Koran Sindo memilih kata mengerem yang sepadan dengan kata mengurangi sedikit demi sedikit. Dari sini terlihat bahwa vonis penjara16 tahun dan denda Rp1 miliar terhadap LHI tidak sepenuhnya akan menghentikan kasus korupsi akan tetapi diharapkan bisa mengurangi sedikit demi sedikit hingga akhirnya kasus korupsi benar-benar berhenti dalam sejarah Indonesia.

f. Retoris

1) Grafis
Merupakan bagian yang dicetak berbeda adalah bagian yang dipandang penting oleh komunikator, dimana ia menginginkan khalayak menaruh perhatian lebih pada bagian tersebut.

Pada berita ini, Koran Sindo menggunakan tipe/font yang cukup besar, untuk judul yang memuat berita tentang vonis terhadap LHI. Hal ini dapat disimpulkan bahwa Koran Sindo memberikan perhatian yang cukup besar terhadap berita ini.

2) Ekspresi

Merupakan elemen untuk memeriksa apa yang ditekankan atau ditonjolkan (sesuatu yang dianggap penting) oleh seseorang dalam suatu teks. Wartawan Koran Sindo menuliskan harapan pakar hukum pidana UIN Syarif Hidayatullah Jakarta Andi Syafrani yang berharap perilaku korup bisa berhenti dengan adanya putusan vonis terhadap LHI.

Andi Syafrani menilai vonis penjara 16 tahun bagi Luthfi merupakan ganjaran tertinggi yang diterima politisi terdakwa korup. Dengan vonis tersebut, seharusnya para penjahat kerah putih bisa jeri dan jera untuk melakukan aksinya. "Jika para pelaku korupsi masih punya rasa takut, saya kira harusnya vonis LHI jadi pelajaran berarti untuk menghentikan perilaku korup," ujarSyafrani.

3) Metafora

Kiasan atau ungkapan yang dimaksudkan sebagai ornamen atau bumbu dari suatu berita. Metafora tertentu dipakai oleh wartawan secara strategis sebagai landasan berfikir, alasan pembenar atas pendapat atau gagasan tertentu kepada publik.

Dengan vonis tersebut, seharusnya para penjahat kerah putih bisa jeri dan jera untuk melakukanaksinya. Koran Sindo menggunakan ungkapan penjahat kerah putih, yang sebenarnya maknanya sama dengan koruptor.

2. Analisis Kognisi Sosial

Pada berita dengan judul "Putusan Lutfi Hasan Diharapkan Jadi Efek Jera”, tampaknya narasumber yang diwawancarai oleh wartawan Koran Sindo lebih banyak yang pro terhadap putusan vonis LHI dibandingkan dengan narasumber yang kontra terhadap putusan tersebut. Terlihat dari lima narasumber yang diwawancarai, empat diantaranya adalah pihak yang mendukung vonis 16 tahun dan denda Rp1 miliar terhadap LHI. Wartawan Koran Sindo 
menuliskan panjang lebar pernyataan-pernyataan kalangan yang mendukung vonis tersebut, sedangkan pendapat kalangan yang kontra hanya ditulis singkat itupun dibagian akhir berita. Dari sini terlihat, seolah wartawan ingin memaparkan penjelasan kalangan yang pro dengan sejelasjelasnya, sedangkan pendapat lainya hanya sebagai pelengkap saja.

\section{Analisis Konteks Sosial}

Pada tanggal 29 Januari 2013, pemberitaan di media massa baik cetak maupun elektronik menghangat dengan pemberitaan kasus suap impor daging sapi. Kasus ini bermula dengan tertangkapnya Ahmad Fathanah dan Maharani di hotel Le Meredian Jakarta. Penangkapan ini menyeret presiden Partai Keadilan Sejahtera (PKS), Lutfi Hasan Ishaq (LHI). Terseretnya LHI dalam kasus suap mengejutkan berbagai pihak, ada yang menganggap penangkapan tersebut sebuah kejanggalan dilakukan oleh $\mathrm{KPK}$, adapula yang menganggap itu sebuah langkah maju KPK.

Dalam sebuah media JPNN edisi Sabtu tanggal 5 Oktober 2013 yang berjudul "Belum Ada Ketentuan Trading Influences di UU Tipikor-Perumus UU Tipikor Kritisi Kejanggalan Kasus Suap Daging Sapi” diberitakan bahwa Pakar hukum Prof Romli Atmasasmita menilai kasus suap dalam pengurusan kuota impor daging sapi yang bermula dari operasi tangkap tangan (OTT) Komisi Pemberantasan Korupsi (KPK) lemah dari sisi korupsi. Menurutnya, unsur memperdagangkan pengaruh (trading influences) yang dituduhkan pada mantan Presiden Partai Keadilan Sejahtera (PKS), Luthfi Hasan Ishaaq, sebenarnya belum diatur dalam pasal-pasal di Undang-Undang Tindak Pidana Korupsi (Tipikor). Da Kemudian hal senada juga disampaikan oleh mantan hakim agung Laica Marzuki pada media yang sama edisi 6 Oktober 2013 dalam pemberitaan yang berjudul "Kasus Suap Kuota Impor Daging Sapi-Aneh, Swasta Duluan Diadili Tapi Pejabat Penerima Suap Masih Dicari”. Laica Marzuki menuturkan bahwa yang tak kalah janggal dalam perkara suap impor daging sapi adalah dakwaan memperdagangkan pengaruh (trading influences) kepada mantan Presiden Partai Keadilan Sejahtera (PKS), Luthfi Hasan Ishaaq.
Padahal, lanjutnya, trading influences belum diatur di dalam Undang-undang Tindak Pidana Korupsi (Tipikor) yang berlaku saat ini.

Selain pemikiran para pakar hukum di atas, kader-kader PKS juga tidak percaya bahwa pemimpin yang mereka teladani terseret bahkan disangakan dalam kasus korupsi. Berbagai opini mereka sampaikan dimedia seperti web, twiter, facebook, bahkan blog. Di antaranya adalah situs web PKS Piyungan. Misalnya Fahri Hamza, dengan terang mengungkapkan kecurigaannya terhadap proses penangkapan LHI ini sebaai sebuahka rekayasa untuk menjtuhkan citra PKS menjelang pemilu 2014.

Kemuadian, dalam sebuah pertanyaan yang dilakukan oleh Najwa Syihab dalam wawancara ekslusif acara Mata Najwa yang live di Metro TV, LHI sendiri mengaku sama sekali tidak mengerti dengan perkara yang dipersangkakan kepadanya. Ia ditangkap oleh KPK pada Rabu malam saat sedang rapat DPP PKS tanpa pemberitahuan terlebih dahulu. Pada saaat itu ia sama sekali tidak mengerti apakah penjemputan yang dilakukan oleh KPK sebagai sebuah pemanggilan semata ataukah sebagai sebuah penagkapan. Pernyatan tersebut dapat diperhatikan dalam petikan/ transkribsi wawancara berikut:

Najwa : "Pak LHI, anda kan terjerat operasi tangkap tangan KPK pada selasa malam di hotel Le Meridien bersama Ahmad Fathonah dan gadis manis bernama Maharani?"

LHI : "saya kurang tahu mbak ya, tapi yg pasti saya dijemput KPK pada Rabu malamnya saat rapat di DPP PKS tanpa pemberitahuan awal [pemanggilan atau penangkapan], termasuk kejelasan status saya saat itu. Yg mbak tanyakan itu saya tidak paham, apalagi barang bukti $1 M$ untuk saya, plus gadis lagi."

Najwa : “jadi, bapak merasa dijebak?”

LHI : "sampai sekarang, saya belum bisa memahami, persoalan apa yang dituduhkan ke saya. Coba mbak tanyakan ke KPK saja, kan mereka yang menangkap dan memiliki 2 alat bukti (katanya) untuk kasus ini. Kalau merasa dijebak, saya biasa saja. Saya menganggap hidup saya berjalan apa adanya. KPK menuduh saya begitu, yaa silahkan dibuktikan. Sebagai 
warga negara, saya akan patuh. Semua kita kan sama didepan hukum mbak, meski waktu itu saya seorang presiden (PKS).

Di sisi yang lain, tak sedikit media yang menyoroti kasus suap impor daging ini dengan menyajikan berita-berita yang menambah citra positif KPK dan sebaliknya menyudutkan LHI bahkan menimbulkan persepsi negative terhadap PKS. Ada media yang mengangkat headline "Partai Kesandung Sapi" yang mengibaratkan bagaimana kasus suap impor daging ini identik dengan PKS

Pemberitaan yang tak kalah hangat dari kasus ini adalah saat keputusan vonis di jatuhkan kepada LHI. LHI dijatuhkan vonis penjara 16 tahun dan denda sebesar Rp 1 Miliar. Vonis ini oleh sebagian media dianggap sebagai vonis yang tepat guna memberikan efek jera terhadap pelaku koruptor. Mereka berpendapat bahwa

Luthfi Hasan Ishaaq divonis hukuman 16 tahun penjara karena terbukti bersalah menerima suap dalam pengaturan kuota impor daging Namun sebagian lainnya meyampaikan bahwa vonis tersebut merupakan tindak ketidakadian yang telah oleh majelis hakim tipikor. Pengacara mantan Presiden Partai Keadilan Sejahtera yaitu Zainudin Paru dan Muhammad Assegaf, membacakan inti keberatan:

"dakwaan dan tuntutan jaksa penuntut umum yang menuntut Luthfi dengan hukuman penjara 18 tahun penjara sangat tidak mencerminkan keadilan. Karena itu, lanjut Assegaf, tuntutan harus batal demi hukum".

Mereka juga menilai bahwa putusan itu tak seimbang jika dibandingkan dengan terdakwa korupsi lainnya yang dijerat KPK. Pasalnya, Luthfi yang tidak menerima uang negara justru dihukum lebih berat dibanding terdakwa korupsi lainnya yang menggasak uang rakyat. Kemudian Zaenudin Paru juga mengaku heran lantaran fakta yang ada di persidangan diabaikan oleh hakim. Sebab, uang Rp 1,3 miliar tidak pernah sampai pada LHI. Selain itu, dua saksi yang bernama Felik Razali dan Ilham, pada persidangan di Pengadilan Tipikor mengakui bahwa mereka datang membawa kwitansi untuk pembayaran Fathanah. Ditambahkannya, hal lain yang diabaikan hakim adalah soal komunikasi via telepon antara Fathanah dengan supirnya, tentang adanya "daging busuk" di mobil sehingga harus dijaga. Anehnya, kata Zaenudin, dalam transkripan justru komunikasi Fathanah dan sopirnya itu menjadi "di mobil ada daging busuk Luthfi". Jadi ada tambahan nama Lutfi dalam percakapan itu. Rekaman yang dibuka tidak seperti keterangan Sahrudin yang tidak menyebut nama LHI dalam percakapan Fathanah dan supirnya. Sehingga kuasa hukum Luthfi ini mensinyalir bahwa jauh sebelum sidang putusan tersebut, vonis untuk Luthfi sudah disiapkan. Selain itu Zaenudin juga melihat intervensi yang begitu kuat terhadap hakim Pengadilan Tipikor. Hal senada juga disampaikan kader PKS di Komisi III DPR, Almuzzammil Yusuf merasa aneh dengan putusan pengadilan atas Luthfi. Dibandingkan para terdakwa korupsi lain yang kerugian negaranya mencapai miliaran rupiah. LHI sendiri merasa dizhalimi dengan putusan tersebut dan akan mengajukan banding melalui kuasa hukumnya.

4. Analisis Terhadap Ideologi Koran Sindo

Dalam analisis wacana, setiap wacana yang muncul tidak dipandang sebagai sesuatu yang alamiah, wajar, dan netral. Akan tetapi merupakan bentuk pertarungan kekuasaan dan ideologi. Konsep kekuasaan yang dimaksudkan adalah salah satu kunci hubungan antara wacana dan masyarakat. Kekuasaan itu dalam hubungannya dengan wacana, penting untuk melihat apa yang disebut kontrol. Kekuasaan dan ideologi Koran Sindo telah menjadi apa yang disebut sebagai kontrol sosial atas pemberitaan vonis kasus korupsi. Kontrol sosial ini dilakukan oleh Koran Sindo dalam bentuk mental psikis. Pihak yang mendukung vonis tinggi terhadap LHI dan berideologi nasionalis nampaknya di tempatkan pada posisi kelompok yang dominan untuk memiliki akses ke media berita Koran Sindo dibandingkan kelompok yang menolak ataupun yang netral. Hal ini terlihat dari dominanya narasumber yang dimintai keterangan mengenai vonis LHI adalah mereka yang mendukung langkah tersebut. Selain itu, dalam teks-teks beritanya, Koran Sindo menuliskan secara detail dan panjang lebar uraian narasumber yang mendukung. Sedangkan pihak yang menolak atau netra hanya dimintai keterangan dalam porsi lebih sedikit 
dibandingkan pihak yang mendukung dan pendapatnya ditulis dalam uraian yang minimalis.

Menurut Teun A. van Dijk kekuasaan dan ideologi media massa dapat dimaksudkan untuk mengatur tindakan dan praktik individu atau anggota suatu kelompok. Ideologi dan kekuasaan Koran Sindo di satu sisi telah menjadikannya untuk bertindak dalam situasi yang sama menghubungkan antara rencana menjerat koruptor dan kedekatannya dengan institusi pemerintah untuk memberikan kontribusi dan membentuk solidaritas terhadap kalangan nasionalis.

Di sisi lain kekuasaan dan ideologi Koran Sindo telah mendorong pembaca untuk melihat bahwa keputusan vonis yang telah ditetapkan oleh majelis hakim adalah keputusan yang pantas tanpa ada cacat-celanya. karena itu wajar kalau putusan majelis hakim harus selalu didukung. Koran Sindo dengan ideologi dan kekuasaannya mengontrol pandangan mental psikis pembaca untuk setidaknya segera memberikan apresiasinya terhadap upaya KPK dan majelis hakim Tipikor dalam memberantas kasus-kasus korupsi.

Dalam analisis wacana kritis teks percakapan dan lainnya yang merupakan bentuk praktik ideologi atau pencerminan ideologi dan kekusaan diciptakan hanya untuk melanggengkan kekusaan tertentu. Tujuannya tidak lain manipulasi ideologi kelompok dominan atas kelompok marjinal melalui kampanye disinformasi baik tentang wacana agama, sosial, politik, ataupun lainnya. Dari teks berita terlihat adanya dominasi kelompok nasionalis terhadap pembaca yang masih bersikap netral atau bahkan terhadap yang antipati dengan kasus-kasus pemberantasan korupsi. Koran Sindo dalam pemberitaan "Putusan Lutfi Diharapkan Jadi Efek Jera" nampaknya menggunakan kesempatan praktik ideologinya untuk membangun citra positif terhadap kinerja KPK dan majelis hakim Tipikor di mata masyarakat Indonesia.

\section{Kesimpulan}

Penelitian mengenai pemberitaan "Putusan Lutfi Diharapkan Jadi Efek Jera” Koran Sindo edisi 11 Desember 2013 dilakukan dengan menggunakan analisis wacana Kritis sebagai alat untuk membedah teks media. Sedangkan pendekatan model TeunA. van Dijk yang sering juga disebut model kognisi sosial. . Berdasarkan data yang telah diteliti maka dapat diambil kesimpulan sebagai berikut :

Wartawan Koran Sindo dalam hal ini bersikap mendukung kinerja KPK dan majelis hakim tipikor. Koran Sindo lebih banyak meminta keterangan kepada pihak yang mendukung pemberantasan korupsi. Hal ini tentunya lebih menguntungkan institusi pemerintah yang bertugas memberantas korupsi. Selain itu pendapat mereka ditulis dengan lengkap, jelas dan detail. Peletakkan hasil wawancara pun selalu ditempatkan di awal berita sehingga kesan yang timbul pendapat mereka dirasa lebih penting dan menarik sehingga pantas untuk diletakkan diawal berita. Sebaliknya, Koran Sindo hanya mewawancarai narasumber dari pihak yang netral atau antipasti dalam porsi yang sedikit, meski kadang menuliskan dan diletakkan di akhir berita. Pemberitaan Koran Sindo Edisi Rabu 11 Desember 2013 "Putusan Lutfi Diharapkan Jadi Efek Jera”. Memanfaatkan kesempatan praktik ideologinya untuk membangun citra KPK dan majelis hakim Tipikor bertambah baik dan positif di mata masyarakat Indonesia.

\section{DAFTAR PUSTAKA}

Eriyanto. 2001. Analisis Wacana. Pengantar Analisis Teks Media. Yogyakarta : LKiS.

Hafizoh. 2007. Analisis Pemberitaan Harian Kompas Tentang Pidato Paus Benedictus XVI (Tidak Dipublikasikan, Skripsi, Fakultas Dakwah IAIN Walisongo).

Sobur, Alex. 2009. Analisis Teks Media, Suatu Pengantar Untuk Analisis Wacana Analisis Semiotik, dan Analisis Framing. Bandung : PT Remaja Rosdakarya.

http://koran-sindo.com/node/350636 di akses tanggal 26/12 2013

http://www.seputar-indonesia.com di akses tanggal 26/12 2013 


\section{PROFIL SINGKAT PENULIS}

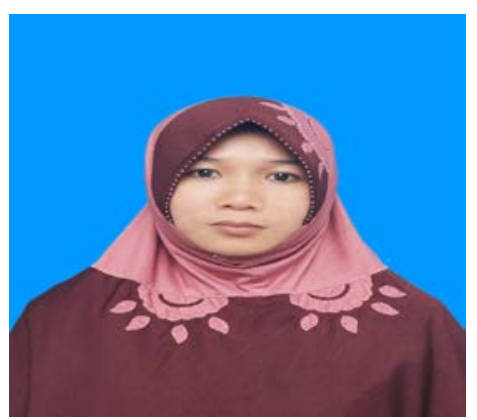

। Dewi Yana, S.Pd., M.Pd., dilahirkan di Sungai Guntung pada tanggal 21 September 1982. Ia memperoleh gelar sarjana Pendidikan di FKIP Universitas Ahmad Dahlan Yogyakarta tahun 2005. Selanjutnya, Ia menempuh pendidkan S2 di Program Linguistik Terapan dengan konsentrasi Pendidikan Bahasa Inggris Universitas Negeri Yogyakarta tahun 20122014. Ia pernah bekerja sebagai instruktur di Global C-Course Yogyakarta pada tahun 20032005 dan menjadi Dosen paruh waktu di STAI IBNU SINA pada tahun 2007-2009. Kemudian, sejak Tahun 2009 sampai sekarang ia menjadi dosen tetap di program studi Pendidikan Bahasa Inggris FKIP UNRIKA Batam. 